\title{
5 Research Square

\section{Increased Nodular P Level Induced by Intercropping Stimulated Nodulation in Soybean Under Phosphorus Deficiency}

\section{Xiao Min Qin}

Yunnan Agricultural University

Hao Nan Pan

Yunnan Agricultural University

Jing Xiu Xiao

Yunnan Agricultural University

Li Tang

Yunnan Agricultural University

Yi Zheng ( $\nabla$ qinxm_1989@163.com )

Yunnan Agricultural University

\section{Research Article}

Keywords: Soybean/maize intercropping, P availability, Nodular P level, Nodulation, Phytase, Acid phosphatases

Posted Date: June 2nd, 2021

DOl: https://doi.org/10.21203/rs.3.rs-548340/v1

License: (c) (1) This work is licensed under a Creative Commons Attribution 4.0 International License. Read Full License

Version of Record: A version of this preprint was published at Scientific Reports on February 7th, 2022. See the published version at https://doi.org/10.1038/s41598-022-05668-z. 


\title{
Increased nodular P level induced by intercropping stimulated nodulation in soybean under phosphorus deficiency
}

\author{
Xiao Min Qin ${ }^{1,2}$, Hao Nan $\operatorname{Pan}^{1}$, Jing Xiu Xiao ${ }^{1}$, Li Tang ${ }^{1}$, Yi Zheng ${ }^{1,3^{*}}$
}

\begin{abstract}
Low $\mathrm{P}$ availability is a vital constraint for nodulation and efficient $\mathrm{N}_{2}$ fixation of legume, including soybean. To elucidate the mechanisms involved in nodule adaption to low $\mathrm{P}$ availability under legume/cereal intercropping systems, two experiments consisting of three cropping patterns (monocropped soybean, monocropped maize, soybean/maize intercropping) were studied under both sufficient- and deficient-P levels. Our results demonstrated that intercropped soybean with maize showed a higher nodulation and $\mathrm{N}_{2}$ fixation efficiency under low $\mathrm{P}$ availability than monocropped soybean as evidenced by improvement in the number, dry weight and nitrogenase activity of nodules. These differences might be attributed to increase in $\mathrm{P}$ level in intercropping-induced nodules under low $\mathrm{P}$ supply, which was caused by the elevated activities of phytase and acid phosphatases in intercropping-induced nodules. Additionally, the enhanced expression of phytase gene in nodules supplied with deficient $\mathrm{P}$ level coincided with an increase in phytase and acid phosphatase activities. Our results revealed a mechanism for how intercropped maize stimulated nodulation and $\mathrm{N}_{2}$ fixation of soybean under P deficient environments, where enhanced synthesis of phytase and acid phosphatases in intercropping-induced nodules, and stimulated nodulation and $\mathrm{N}_{2}$ fixation.
\end{abstract}

\section{Keywords}

Soybean/maize intercropping; P availability; Nodular P level; Nodulation; Phytase; Acid phosphatases

${ }^{1}$ College of Resources and Environmental Science, Yunnan Agricultural University, Kunming 650201, China

${ }^{2}$ Guangxi South Subtropical Agricultural Science Research Institute, Chongzuo, China

${ }^{3}$ Yunnan Open University, Kunming 650599, China

* Corresponding authors: Yi Zheng; Current address: College of Resources and Environmental Science, Yunnan Agricultural University, Kunming 650201, China; Email: yzheng@ ynau.edu.cn. 


\section{Introduction}

Phosphorus is one of the most important macronutrients for plant growth and development, and plays a vital role in increasing crop yield ${ }^{[1-2]}$. Unfortunately, low $\mathrm{P}$ availability in many agricultural soils is nearly universal, because $\mathrm{P}$ massively precipitates to form various unavailable complexes with metals, such as iron and aluminium in acidic soil ${ }^{[3-4]}$. Furthermore, $\mathrm{P}$ deficiency in soils in agriculture production relies on continual supply of $\mathrm{P}$ fertilizers which will trigger greater environmental risks and $\mathrm{P}$ resource loss. Additionally, mineral $\mathrm{P}$ resources are non-renewable and global high-grade rock phosphates are estimated to be depleted within 100 years ${ }^{[5-6]}$. Consequently, the influence of limiting the input of $\mathrm{P}$ to agricultural ecosystem is going to become a global problem.

Legume, as a key part of sustainable agro-ecosystem, plays an important role in effective management of fertilizers and improving soil health ${ }^{[7]}$. However, low P availability in soils is one of the most obvious abiotic factors that limits the growth and productivity of legume, because of the decrease in $\mathrm{N}_{2}$ fixation ${ }^{[8-9]}$. For nodules in particular, the role of $\mathrm{P}$ is crucial in the metabolic reactions that drive symbiotic $\mathrm{N}_{2}$ fixation ${ }^{[10-12]}$. A reduction of $\mathrm{P}$ levels in nodules under $\mathrm{P}$ starvation, resulting in significant declines in nodule formation, nitrogenase activity and $\mathrm{N}_{2}$ fixation ${ }^{[13-15]}$.Thus, the symbiotic $\mathrm{N}_{2}$ fixation efficiency of nodulated legume is most likely determined by $\mathrm{P}$ level within the nodules ${ }^{[16]}$.

Intercropping, growing simultaneously two or more crop species within the same space during a considerable part of their lifecycle ${ }^{[17]}$; and legume/cereal intercropping is a classical case. A large number of results derived from field and pot experiments have proved that intercropping of legume and cereal could enhance the efficient utilization of phosphorus and yield through interspecific facilitation, even under phosphorus deficient conditions ${ }^{[18-21]}$. Additionally, evidences had accumulated recently that the practice of intercropped legume with cereal promoted the nodulation and $\mathrm{N}_{2}$ fixation of legume by interspecific facilitation, and resulted in increased $\mathrm{N}$ uptake of associated cereal ${ }^{[22-24]}$. Considering the interspecific facilitation, we hypothesized that $\mathrm{P}$ level in nodules of legume under $\mathrm{P}$ stressful environment would be stimulated by intercropping.

Acid phosphatase (APase), as a unique group of enzymes, plays an important role in internal $\mathrm{P}$ homeostasis by the production, transport and remobilization of phosphorus ${ }^{[25]}$. Particularly phytase, as one of the most interesting classes of APase, catalyzes the release of phosphate from phytate; and phytic acid is the principal storage form of phosphorus in tissues of higher plants ${ }^{[26-27]}$. Significant increase in synthesis and secretion of acid phosphatases in legume respond to $\mathrm{P}$ stress to stimulate effective utilization of internal and external phosphorus, particularly under legume/cereal intercropping patterns consisting of faba bean/maize and peanut/maize $\left[{ }^{28-30]}\right.$. In legume nodules, phytase and acid phosphatase also had been observed, and it had been demonstrated that their elevated activities induced by $\mathrm{P}$ deficiency resulted in a higher nodular $\mathrm{P}$ level ${ }^{[31-33]}$. However, how intercropped cereal induced the synthesis of phytase and acid phosphatases in nodules by root-root interaction under P stressful environments and their specific role in affecting nodular P level remain poorly documented.

Soybean (Glycine max L.) widely is adopted to intercrop with other cereals in the world due to its superior ability in $\mathrm{N}_{2}$ fixation ${ }^{[34]}$. The intercropping of soybean and maize is widely practiced as a promising option in China, due to its outstanding advantages in improvement of nutrient $(\mathrm{N}$ and $\mathrm{P})$ use efficiency and yield ${ }^{[35-37]}$. Much work on improvement of $\mathrm{P}$ content in nodules under $\mathrm{P}$ deficiency today were mainly focused on soybean grown alon ${ }^{[38,13,15]}$, but little information is available about the $\mathrm{P}$ level in nodules altered by intercropping of soybean and maize. In this context, in order to elucidate the interaction of $\mathrm{P}$ deficiency-nodular $\mathrm{P}$ level-nodulation under soybean/maize intercropping, we 
conducted experiments under both sufficient and deficient $\mathrm{P}$ levels to test the hypothesis that intercropped soybean and maize grown under P-deficient conditions could increase the P level in nodules. We also hypothesized that activities of acid phosphatase and phytase in nodules highly stimulated by intercropping of soybean and maize under $\mathrm{P}$ deficiency would result in elevated nodular P level.

\section{Results}

\section{Plants Growth}

Intercropping significantly increased biomass compared to monocropping at two levels of $\mathrm{P}$ supply in two experiments (Table. 1). In soil and hydroponic experiments, total shoot and root dry matter (DM) accumulations in intercropped soybean supplied with deficient or sufficient P levels were significantly greater than that in monocropped soybean, respectively, and the shoot and root DW of intercropped maize were significantly enhanced compared to monocropped maize. A reduction in $\mathrm{P}$ supply resulted in a significant decrease in DM accumulation in shoots and roots in both maize and soybean. Root DM was more affected than shoot DM under deficient P conditions in soybean. This observation was particularly evident in soybean as evidenced by the significant decrease in the ratio of root to shoot when the $\mathrm{P}$ supply reduced.

Table 1 Effects of intercropping on growth of soybean and maize under two P levels

\begin{tabular}{|c|c|c|c|c|c|c|c|c|}
\hline \multirow{2}{*}{ Experiments } & \multirow{2}{*}{ Times } & \multirow{2}{*}{$\begin{array}{c}\text { Cropping } \\
\text { patterns }\end{array}$} & \multicolumn{2}{|c|}{ Shoots/g.plant ${ }^{-1}$} & \multicolumn{2}{|c|}{ Roots/g.plant ${ }^{-1}$} & \multicolumn{2}{|c|}{ Root/Shoot ratio } \\
\hline & & & Deficient-P & Sufficient-P & Deficient-P & Sufficient-P & Deficient-P & Sufficient-P \\
\hline \multirow[b]{2}{*}{ Soil } & \multirow{4}{*}{$75 d$} & MS & $8.15 \pm 0.12 d$ & $12.40 \pm 0.24 \mathrm{c}$ & $1.16 \pm 0.09 \mathrm{~d}$ & $2.48 \pm 0.14 b$ & $0.142 b$ & $0.200 \mathrm{a}$ \\
\hline & & IS & $13.79 \pm 0.80 \mathrm{~b}$ & $17.02 \pm 0.67 \mathrm{a}$ & $2.17 \pm 0.12 b$ & $3.52 \pm 0.13 \mathrm{a}$ & $0.157 b$ & $0.207 \mathrm{a}$ \\
\hline \multirow{2}{*}{ experiment } & & MM & $15.55 \pm 0.44 d$ & $22.85 \pm 1.02 \mathrm{c}$ & $3.69 \pm 0.16 c$ & $5.11 \pm 0.20 b$ & $0.237 \mathrm{a}$ & $0.224 \mathrm{a}$ \\
\hline & & $\mathrm{IM}$ & $24.39 \pm 0.47 b$ & $31.21 \pm 1.20 \mathrm{a}$ & $5.46 \pm 0.27 b$ & $6.66 \pm 0.52 a$ & $0.224 \mathrm{a}$ & $0.214 \mathrm{a}$ \\
\hline \multirow{2}{*}{ Hydroponic } & \multirow{4}{*}{$62 d$} & MS & $6.75 \pm 0.12 c$ & $8.26 \pm 0.39 b$ & $0.85 \pm 0.04 c$ & $1.18 \pm 0.09 b$ & $0.126 \mathrm{c}$ & $0.144 b$ \\
\hline & & IS & $8.57 \pm 0.25 b$ & $10.33 \pm 0.46 \mathrm{a}$ & $1.24 \pm 0.15 b$ & $2.02 \pm 0.11 \mathrm{a}$ & $0.145 b$ & $0.195 \mathrm{a}$ \\
\hline \multirow{2}{*}{ experiment } & & MM & $7.49 \pm 0.73 c$ & $9.43 \pm 0.16 b$ & $1.93 \pm 0.12 \mathrm{~d}$ & $2.13 \pm 0.13 c$ & $0.259 \mathrm{a}$ & $0.226 b$ \\
\hline & & $\mathrm{IM}$ & $9.68 \pm 0.42 b$ & $12.73 \pm 0.18 \mathrm{a}$ & $2.49 \pm 0.15 b$ & $2.78 \pm 0.09 \mathrm{a}$ & $0.257 \mathrm{a}$ & $0.219 \mathrm{~b}$ \\
\hline
\end{tabular}

MS: monocropped soybean IS: intercropped soybean MM: monocropped maize IM: intercropped maize. Different lowercase letters denoted significant difference between monocropped and intercropped treatments under different $\mathrm{P}$ levels $(\mathrm{P} \leq 0.05)$.

\section{Soybean Nodulation}

Intercropping significantly stimulated soybean nodulation compared to monocropping in both soil and hydroponic experiments (Table.2). On the $75^{\text {th }} \mathrm{d}$ in the soil experiment, nodule number and nodule dry weight of intercropped soybean under both deficient and sufficient P levels increased by $73.91 \%$, $82.95 \%$ and $99.56 \%, 62.70 \%$ respectively, compared to monocropped soybean (Table.2). Also in the hydroponic experiment $\left(62^{\text {th }} \mathrm{d}\right)$, intercropping significantly increased the number and dry weight of nodules on soybean roots by $64.00 \%, 56.41 \%$ and $30.10 \%, 50.64 \%$ at two levels of $\mathrm{P}$ supply, respectively (Table.2). However, soybean nodulation was significantly inhibited by low $\mathrm{P}$ supply in both soil and hydroponic experiments, which might be explained by the observed significant decline in the number and dry weight of soybean nodules.

Nitrogenase activity of nodules is one of indices assessing $\mathrm{N}_{2}$ fixation efficiency of leguminous plants. Nitrogenase activity in soybean nodules was frequently enhanced when intercropped with maize than grown alone at two levels of P supply (Fig.1). In both soil and hydroponic experiments, the nitrogenase activity in intercropping-induced nodules significantly increased by $35.29 \%, 14.36 \%$ and $25.17 \%$, $13.71 \%$ under both deficient and sufficient $\mathrm{P}$ levels than monocropping, respectively. Nevertheless, the nodule nitrogenase activities of either inter- or mono-cropped soybean grown under deficient $\mathrm{P}$ condition were decrease in both soil and hydroponic experiments. 
Table 2 Effects of intercropping on nodule number and nodule dry weight of soybean under two P levels

\begin{tabular}{|c|c|c|c|c|c|c|}
\hline \multirow{2}{*}{ Experiments } & \multirow{2}{*}{ Times } & \multirow{2}{*}{$\begin{array}{c}\text { Cropping } \\
\text { patterns }\end{array}$} & \multicolumn{2}{|c|}{ Nodule number/NO.plant ${ }^{-1}$} & \multicolumn{2}{|c|}{ Nodule dry weight/g. plant $^{-1}$} \\
\hline & & & Deficient-P & Sufficient-P & Deficient-P & Sufficient-P \\
\hline \multirow{2}{*}{$\begin{array}{c}\text { Soil } \\
\text { experiment }\end{array}$} & \multirow{2}{*}{$75 \mathrm{~d}$} & MS & $23 \pm 0.90 \mathrm{~d}$ & $32 \pm 0.74 \mathrm{c}$ & $0.132 \pm 0.00 \mathrm{~d}$ & $0.191 \pm 0.01 \mathrm{c}$ \\
\hline & & IS & $40 \pm 1.18 b$ & $59 \pm 1.29 \mathrm{a}$ & $0.263 \pm 0.01 b$ & $0.312 \pm 0.01 \mathrm{a}$ \\
\hline \multirow{2}{*}{$\begin{array}{l}\text { Hydroponic } \\
\text { experiment }\end{array}$} & \multirow{2}{*}{$62 d$} & MS & $25 \pm 1.53 \mathrm{~d}$ & $39 \pm 1.75 \mathrm{c}$ & $0.196 \pm 0.01 \mathrm{c}$ & $0.233 \pm 0.01 b$ \\
\hline & & IS & $41 \pm 1.55 b$ & $61 \pm 1.27 \mathrm{a}$ & $0.255 \pm 0.02 b$ & $0.351 \pm 0.02 \mathrm{a}$ \\
\hline
\end{tabular}

MS: monocropped soybean IS: intercropped soybean. Different lowercase letters indicated significant difference between monocropped and intercropped treatments under different P levels at 0.05 leve1.
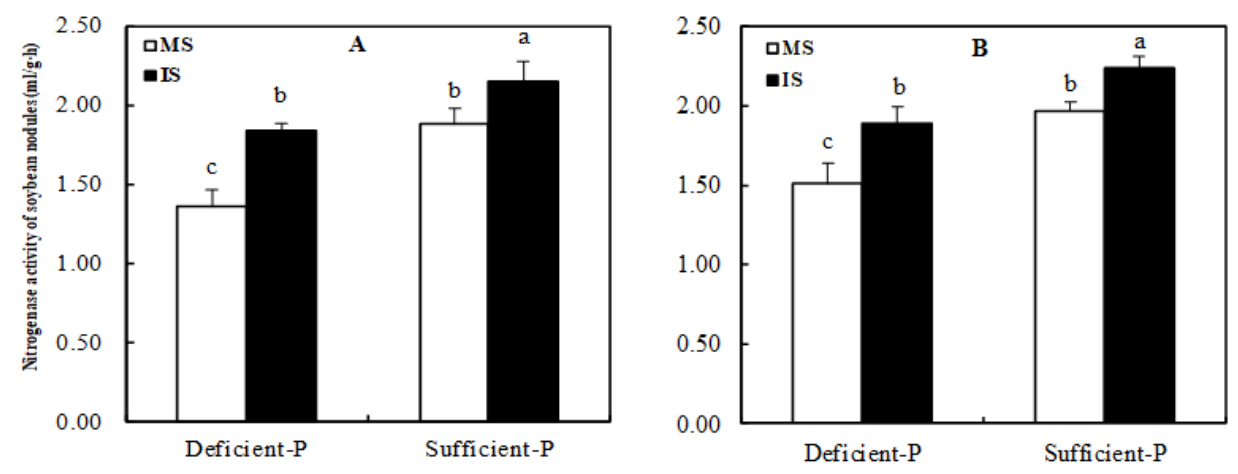

Fig. 1 Effects of intercropping on nodule nitrogenase activity of soybean

MS: monocropped soybean IS: intercropped soybean. A: soil experiment B: hydroponic experiment. Different lowercase letters indicated significant difference between monocropped and intercropped treatments under different P levels at 0.05 leve 1 .

\section{P Levels in Soybean Leaves, Nodules and Roots}

$\mathrm{P}$ levels in nodules of intercropped soybean under both deficient and sufficient P levels increased by $15.08 \%$ and $22.07 \%$ in the soil experiment $\left(75^{\text {th }} \mathrm{d}\right)$ respectively, compared to monocropped soybean (Fig.2). Similarly, the P levels in intercropping-induced nodules supplied with two P levels enhanced by $19.47 \%$ and $23.19 \%$ on the $62^{\text {th }} \mathrm{d}$ in the hydroponic experiment. Also in leaves and roots, P levels of intercropped soybean in both soil and hydroponic experiments were higher than that in monocropped soybean.

Low $\mathrm{P}$ supply resulted in a significant decrease in $\mathrm{P}$ levels in leaves and roots of intercropped- or monocropped-soybean in both soil and hydroponic experiments (Fig.2); the reduction in the soil experiment ( $11.53 \%$ and $20.22 \%$ for leaves, $22.64 \%$ and $30.41 \%$ for roots) and the reduction in the hydroponic experiment (23.26\% and $34.5 \%$ for leaves, $29.28 \%$ and $41.80 \%$ for roots); whereas there were no significant decline in nodular P levels. P level in nodules of soybean whether deficient- or sufficient-P conditions remarkably greater than those in leaves and roots.
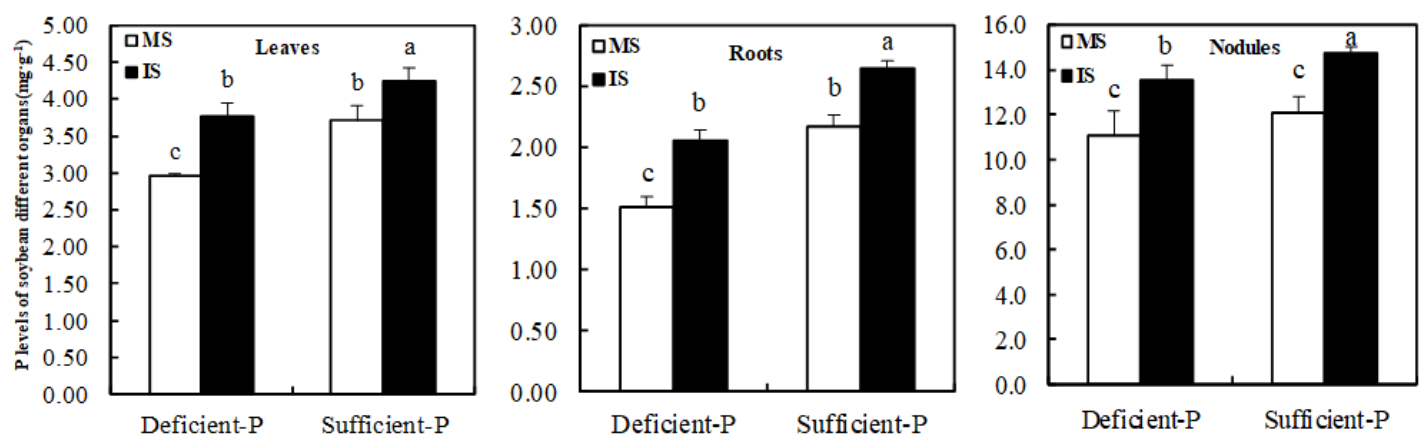

Soil experiment 

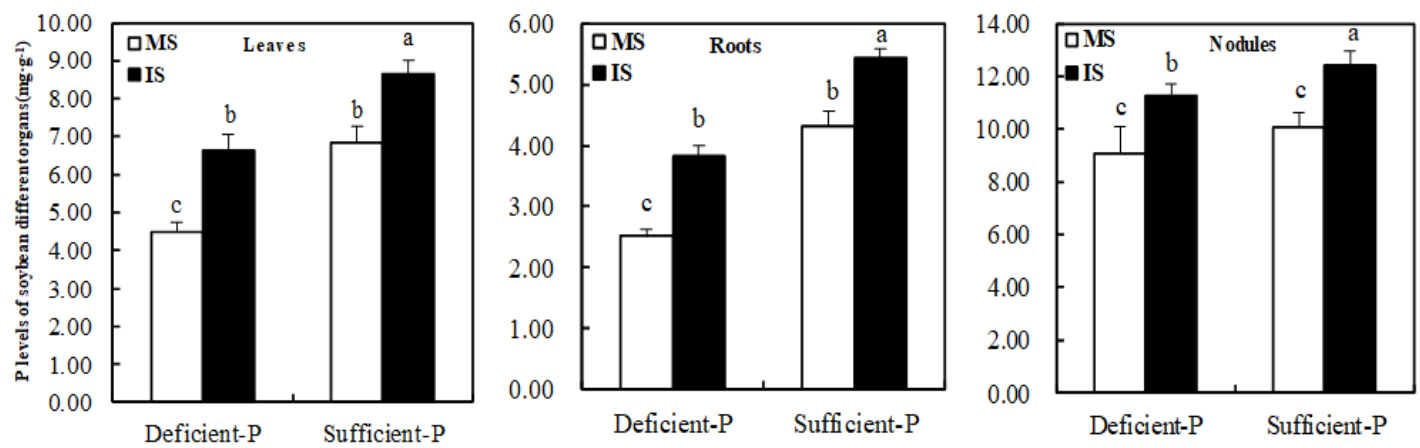

Hydroponic experiment

Fig. 2 Effects of intercropping on $P$ concentration of soybean different tissues under different $P$ rates MS: monocropped soybean IS: intercropped soybean. Different lowercase letters indicated significant difference between monocropped and intercropped treatments under different $\mathrm{P}$ levels at 0.05 leve 1.

\section{Acid Phosphatase (APase) and Phytase Activities in Soybean Nodules, Roots, and Leaves}

Induction of key enzymes involved in improvement of internal P utilization efficiency displayed a profound variation in response to cropping patterns and P supply (Fig.3 and Fig.4). On the $75^{\text {th }} \mathrm{d}$ in the soil experiment, APase activities in nodules, leaves and roots of intercropped soybean under both deficient and sufficient P levels significantly enhanced by $13.72 \%$ and $9.76 \%, 11.68 \%$ and $16.68 \%$, $22.74 \%$ and $32.24 \%$ than monocropping, respectively, as well as the phytase activities (18.28\% and $8.40 \%, 20.21 \%$ and $12.29 \%, 20.88 \%$ and $13.84 \%)$. Also in the hydroponic experiment $\left(62^{\text {th }} d\right)$, intercropping caused a significant enhancement in the activities of APase and phytase in nodules, leaves and roots relative to monocropping at two levels of $\mathrm{P}$ supply.

Reduced P supply resulted in a significant increase in the activities of APase and phytase in nodules of either inter-or mono-cropped soybean, as well as their leaves and roots. And the activity of APase and phytase in nodules much higher than those in leaves and roots. Particularly, the activities of APase and phytase in nodules of intercropped soybean supplied with deficient $\mathrm{P}$ level reached the maximum, as well as leaves and roots.
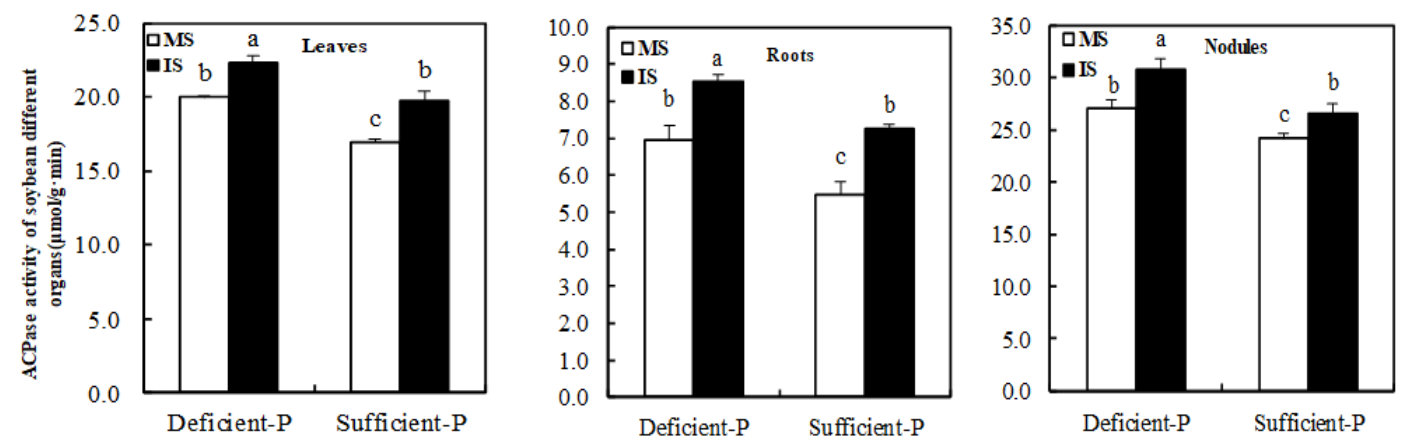

\section{Soil experiment}



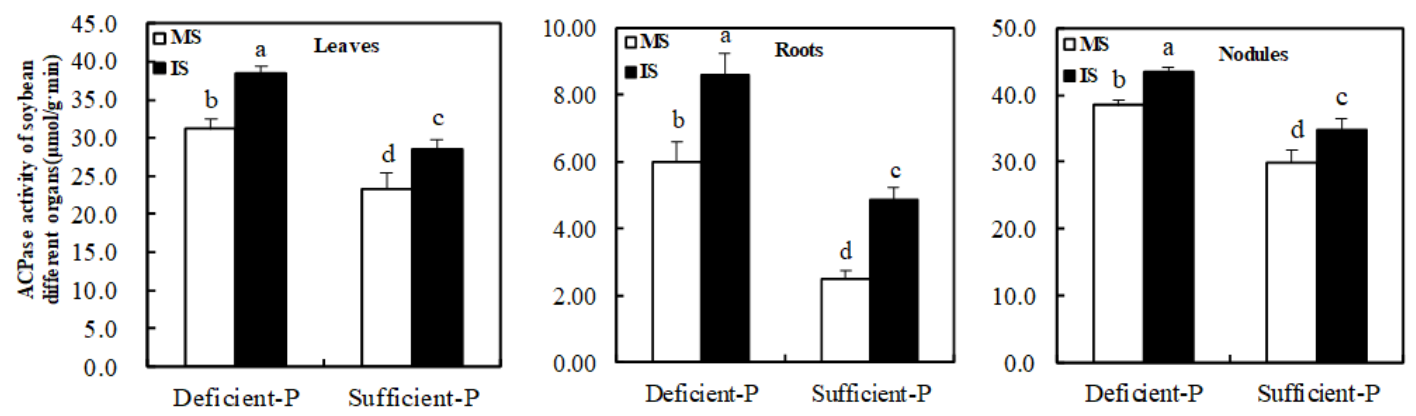

Hydroponic experiment

Fig. 3 Effects of intercropping on APase activity of soybean different organs under different P rates MS: monocropped soybean IS: intercropped soybean. Different lowercase letters indicated significant difference between monocropped and intercropped treatments under different $\mathrm{P}$ rates at 0.05 leve 1 .
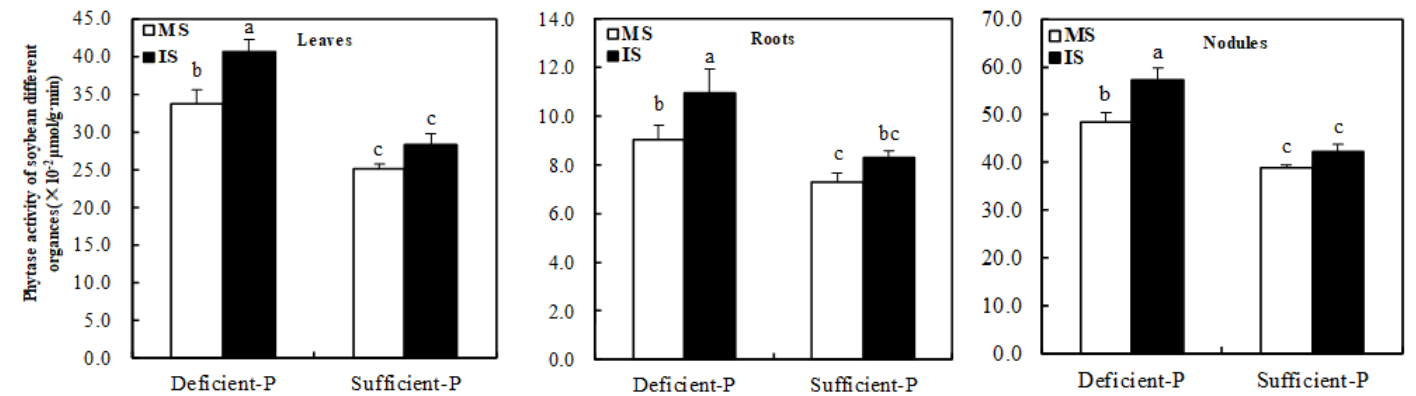

Soil experiment
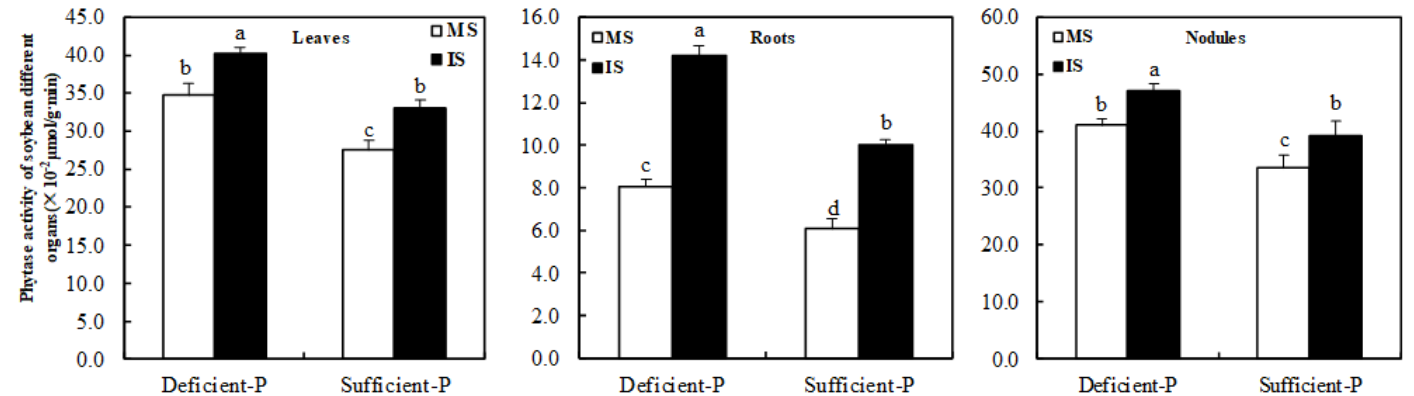

Hydroponic experiment

Fig. 4 Effects of intercropping on phytase activity of soybean different organs under different $P$ rates

MS: monocropped soybean. IS: intercropped soybean. Different lowercase letters mean the significant difference between monocropped and intercropped treatments under different $P$ levels at 0.05 leve1.

\section{Expression of Phytase gene in Soybean Nodules}

The expression level of phytase gene in nodules was significantly induced by intercropping under both deficient- and sufficient-P levels (Fig.5), as indicated by 63\% and $85 \%$ increases in soil and hydroponic experiments compared with soybean grown alone, respectively. And, the expression level of phytase gene in nodules of either inters-or mono-cropped soybean significantly enhanced in response to low P supply in both experiments. Moreover, the expression level of phytase gene in nodules of intercropped soybean at low P supply reached the maximum in both experiments. 

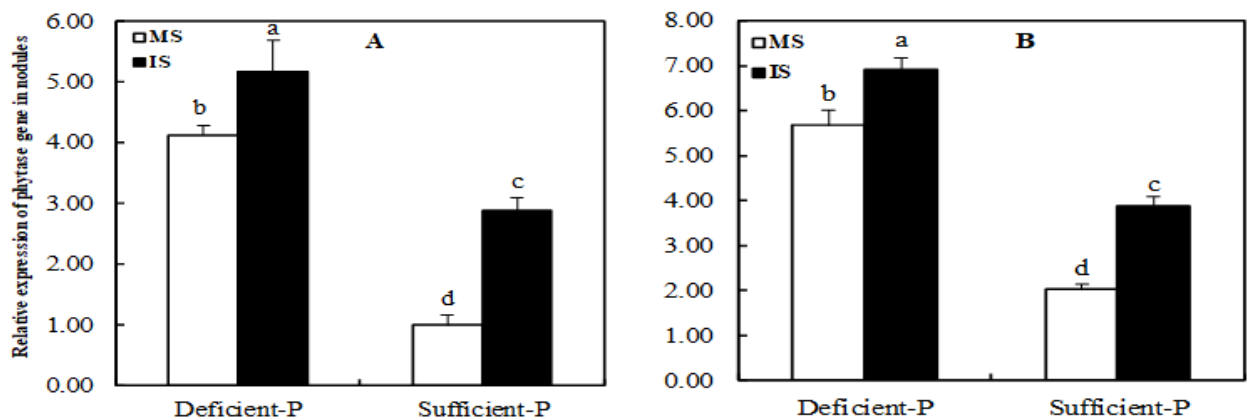

Fig. 5 Effects of intercropping on relative expression of phytase gene in soybean nodules under different $P$ rates MS: monocropped soybean IS: intercropped soybean. A: soil experiment B: hydroponic experiment. Different lowercase letters indicated significant difference between monocropped and intercropped treatments under different P levels at 0.05 leve 1 .

\section{Discussions}

Legume/cereal intercropping is widely practiced as a sustainable food-production pathway in tropical and temperate regions ${ }^{[39]}$, due to it could reduce the input of industrial $\mathrm{N}$ fertilizer by enhancing the symbiotic $\mathrm{N}_{2}$ fixation of associated legume ${ }^{[40-41]}$. Both soil and hydroponic experiments revealed that nodulation and $\mathrm{N}_{2}$ fixation were enhanced when soybean intercropped with maize than grown alone, even under low P supply, which might be evidenced by the observed significant increase in the number, dry weight and nitrogenase activity of nodules (Table. 2). Then, improved nodulation of soybean in intercropping under $\mathrm{P}$ deficient condition facilitated the growth of soybean and neighbouring maize (Table.1). Our results were in line with other previous studies on legume/cereal intercropping systems such as faba bean/wheat ${ }^{[24]}$, faba bean/maize ${ }^{[22]}$ and pea/maize ${ }^{[23]}$ in terms of nodulation and $\mathrm{N}_{2}$ fixation.

The high $\mathrm{N}_{2}$ fixation efficiency of legume would largely depend on efficient $\mathrm{P}$ allocation and the elevated P concentrations in nodules, particularly under P stressful environments ${ }^{[42,13,43]}$. Up to $20 \%$ of total plant $\mathrm{P}$ was preferentially partitioned to nodules to support nodule efficient $\mathrm{N}_{2}$ fixation, even much higher $\mathrm{P}$ under phosphorus starvation conditions ${ }^{[44,8]}$. $\mathrm{P}$ concentrations in legume nodules were remarkably higher than that in any other organs to improve $\mathrm{N}_{2}$ fixation efficiency, even over three-folds undergoing P-limited conditions ${ }^{[16]}$. Our experiments also found that $\mathrm{P}$ levels in nodules of soybean supplied with sufficient- or deficient-P levels apparently greater than that in leaves or roots (Fig.2), even up to 10-folds. These data implied that nodule was a strong P sink with an ability of maintaining the nodular $\mathrm{P}$ homeostasis.

A reduction of $\mathrm{P}$ levels in nodules, roots and leaves of soybean under P deficiency (Fig.2) agreed with previous observations of Esfahani et al., who reported that low $\mathrm{P}$ supply resulted in an apparent decline in P levels in nodules, roots and leaves of MmSWRI9-inoculated chickpea ${ }^{[45]}$. Interestingly, however, intercropped soybean with maize could significantly increase P levels in nodules, roots and leaves whether P deficient or sufficient levels compared with monocropped soybean(Fig.2), indicating that intercropping of soybean and maize possessed an interspecific facilitation that more efficiently improve internal P contents than monocropped soybean. More interestingly, P level in nodules of intercropped soybean supplied with deficient $\mathrm{P}$ was significantly higher than that in nodules of monocropped soybean with P sufficient level. These observed results in present experiments together suggested that intercropped soybean with maize could improve P content in nodules by interspecific facilitation under $\mathrm{P}$ deficient conditions. 
Phosphatase and particularly phytase are involved in the enhancement of P uptake and its internal use and recycling within the plant tissues ${ }^{[46-47]}$. The same results were made in some studies on common bean nodules ${ }^{[31,48-49]}$, which suggested that these plant phytase and APase were most likely involved in $\mathrm{P}$ homoeostasis in the nodules under P starvation. In present study, the enhanced activities of phytase and APase in nodules of either monocropped or intercropped soybean were observed under low P supply, revealing phytase and APase might be involved in the improvement of P level in nodules, and agreed with previous observations on common bean and faba bean ${ }^{[0-51]}$. Remarkably, the elevated expression level of phytase gene in the nodules under P deficiency (Fig. 5) coincided with the increased activities of nodular phytase and APase (Fig.3 and Fig.4), indicating the involvement of this particular gene in nodular $\mathrm{P}$ homoeostasis by enhancing the activities of phytase and APase, and agreed with results of Araújo et al. ${ }^{[31]}$ and Lazali et al. ${ }^{[33]}$ on common bean.

Indeed, intercropped soybean with maize could significantly increase the activities of phytase and APase, and expression level of phytase gene in nodules as compared to monocropped soybean(Fig. 3, 4 and 5), revealing that soybean/maize intercropping could induce the synthesis of phytase and APase in nodules. Furthermore, the maximum activities of phytase and APase as well as the highest expression of phytase gene in nodules of intercropped soybean supplied with low $\mathrm{P}$ were observed relative to other treatments (Fig.3, 4 and 5). These findings in present experiments comprehensively elucidated that the enhancement of P level in nodules was most likely caused by improvement of phytase and APase activities when soybean intercropped with maize under $P$ deficient conditions.

\section{Conclusions}

Our results suggest that the enhanced nodulation in soybean/maize intercropping system under $\mathrm{P}$ deficiency induced by elevated $\mathrm{P}$ level in nodules, as compared to monocropped soybean. The increased activities of phytase and acid phosphatases in intercropping-induced nodules under low supply of $\mathrm{P}$ fertilizer were considered as one of important forces driving enhancement in nodular $\mathrm{P}$ level. The expression of phytase gene was positively associated with the activities of phytase and APase in nodules. We concluded that the expression and activity of phytase in nodules under low $\mathrm{P}$ conditions played a pivotal role in symbiotic $\mathrm{N}_{2}$ fixation, but the quantitative expression of the genes involving in the nodule function should be further investigated. Our results would advance our understanding on the underlying mechanisms of interspecific facilitation on nodulation and $\mathrm{N}_{2}$ fixation in legume/cereal intercropping systems, particularly under P stressful environments.

\section{Materials and methods}

\section{Materials and growth conditions}

All experiments involving plants were carried out in accordance with relevant institutional, national, and international guidelines and legislation.

\section{Experimental design}

Soil Experiment A pot experiment was conducted with three cropping patterns and two $\mathrm{P}$ supplies. Soybean or maize was grown alone as a monocropping pattern (monocropped soybean, monocropped maize), or intercropped with maize (soybean//maize) in soil supplied with 50 and $100 \mathrm{mg}$ $\mathrm{P} \mathrm{kg}^{-1}$ soil, corresponding to deficient-P and sufficient-P levels, respectively. There were six treatments with four replicates per treatment in this experiment.

The tested soil was collected from Xiaoshao experimental station in Kunming $\left(102^{\circ} 99^{\prime} \mathrm{E}\right.$, 
$25^{\circ} 17^{\prime} \mathrm{N}$ ), Yunnan province, China and it was a typical red soil with a strong capacity of phosphorus fixation. Soil properties were as follows: Olsen-P $4.77 \mathrm{mg} \cdot \mathrm{kg}^{-1}$, organic C $7.58 \mathrm{~g} \cdot \mathrm{kg}^{-1}$, available $\mathrm{N}$ $30.87 \mathrm{mg} \cdot \mathrm{kg}^{-1}$, available $\mathrm{K} 125.44 \mathrm{mg} \cdot \mathrm{kg}^{-1}$ and $\mathrm{pH} 5.19$ (the ratio of soil to distilled water was $1: 2.5$ ). Each pot $(24 \mathrm{~cm}$ height $\times 19.5 \mathrm{~cm}$ diameter) was filled with $10 \mathrm{~kg}$ of air-dried soil. To ensure that the nutrient supply was adequate for plant growth, $150 \mathrm{mg} \mathrm{N} \mathrm{kg}^{-1}$ soil and $150 \mathrm{mg} \mathrm{K} \mathrm{kg}^{-1}$ soil were also fertilized with basal nutrients. Urea, superphosphate, and potassium sulfate were applied in the soil experiment as $\mathrm{N}, \mathrm{P}$ and $\mathrm{K}$ fertilizers.

The genotype of soybean (Glycine max L.) was Diandou-7(Authorized No.:2010017), and the genotype of maize (Zea mays L.) was Yunrui-88(Authorized No.: 2009012), provided by Yunnan Academy of Agricultural Sciences. The seeds of soybean and maize were surface sterilized with $75 \%$ ( $\mathrm{vol} / \mathrm{vol}$ ) alcohol for $5 \mathrm{~min}$ and rinsed with sterilized distilled water and then, sterilized with $15 \%$ ( vol/vol) $\mathrm{H}_{2} \mathrm{O}_{2}$ for $10 \mathrm{~min}$ and rinsed with sterilized distilled water, and then germinated in a growth chamber of $22{ }^{\circ} \mathrm{C}$ for $48 \mathrm{~h}$ under dark. Then, the germinated seeds of soybean or maize were uniformly planted in two rows in each pot in monocropped pattern, while intercropping designed with a row of soybean and a row of maize based on the replacement principle. All of the pots were arranged in a completely randomized block design and were re-randomized weekly during the experimental period. All soybean plants were inoculated with a suspension of $\sim 10^{8}$ cells $\mathrm{mL}^{-1}$ of rhizobium strains BNCC336406 (R. Bradyrhizobium japonicum (Kirchner) Jordan). The plants were watered every day to maintain field capacity $(20 \% \sim 25 \%$, w/w).

At $75 \mathrm{~d}$ (flowering stage), leaves, roots, and nodules were separately harvested for measuring dry weight, $\mathrm{P}$ content, nodule number and nodule dry weight. In addition, fractions of leaf, root, and nodule used for assays of enzyme activity, gene expression were frozen immediately in liquid $\mathrm{N}_{2}$, and stored at $-80^{\circ} \mathrm{C}$.

Hydroponic experiment. A hydroponic experiment was set up with three cropping patterns (soybean, maize and soybean/maize) and two $\mathrm{P}$ supplies (deficient-P and sufficient-P levels). There were six treatments arranged in a complete randomized block design with 4 replicates of each treatment.

The same genotypes of maize and soybean seeds were chosen and handled as in the soil experiment. After germination, the young seedlings of soybean were inoculated with a suspension of rhizobium strains BNCC336406 $\left(\sim 10^{8}\right.$ cells $\left.\mathrm{mL}^{-1}\right)$. The planting density of soybean and maize plants in monocropping or intercropping pattern was same as in the soil experiment.

Then, these seedlings of inoculated soybean and maize were transplanted into each $3 \mathrm{~L}$-container filled with full nutrients containing $2000 \mu \mathrm{M} \mathrm{Ca}\left(\mathrm{NO}_{3}\right)_{2}, 750 \mu \mathrm{M} \mathrm{K}_{2} \mathrm{SO}_{4}, 650 \mu \mathrm{M} \mathrm{MgSO}, 100 \mu \mathrm{M} \mathrm{KCl}$, $0.1 \mu \mathrm{M} \mathrm{H}_{3} \mathrm{BO}_{3}, 1 \mu \mathrm{M} \mathrm{MnSO}_{4}, 0.1 \mu \mathrm{M} \mathrm{CuSO}_{4}, 1 \mu \mathrm{M} \mathrm{ZnSO} \mathrm{Z}_{4}, 0.005 \mu \mathrm{M}(\mathrm{NH} 4)_{6} \mathrm{Mo}_{7} \mathrm{O}_{24}, 100 \mu \mathrm{M}$ Fe-EDTA, and $\mathrm{KH}_{2} \mathrm{PO}_{4}$ was supplemented to the nutrient solution to a concentration of either $250 \mu \mathrm{M}$ or $125 \mu \mathrm{M}$ to establish sufficient or deficient P levels, respectively. An appropriate concentration of $\mathrm{K}_{2} \mathrm{SO}_{4}$ was added to the P-deficient solution to ensure an equal supply of $\mathrm{K}$. The $\mathrm{pH}$ of nutrient solution was adjusted to 5.5 with $\mathrm{HCl}\left(0.01 \mathrm{~mol} \cdot \mathrm{L}^{-1}\right)$. The nutrient solution was replaced two times every week until harvest. The oxygenation of nutrient solution was ensured by a permanent flow of 400 $\mathrm{ml} \min ^{-1}$ of compressed air. At $62 \mathrm{~d}$ (flowering stage), leaves, roots, and nodules were separately harvested and determined as in the soil experiment.

Both experiments were conducted in a glasshouse at Yunnan Agricultural University (YNAU), Kunming (latitude: $40^{\circ} 08^{\prime} \mathrm{N}$, longitude: $102^{\circ} 48^{\prime} \mathrm{E}$ ). In the soil experiment, the temperature in the glasshouse was maintained at $24-32^{\circ} \mathrm{C}$ during the day and $15-18^{\circ} \mathrm{C}$ at night, with $12-14 \mathrm{~h}$ daytime 
throughout the growth period. In hydroponic experiment, temperature was maintained at $25-30^{\circ} \mathrm{C}$ during the day and $18-21^{\circ} \mathrm{C}$ at night, with $14-16 \mathrm{~h}$ daytime.

\section{Measurements}

Plant biomass and $\mathbf{P}$ content Shoots, roots and nodules were dried at $75^{\circ} \mathrm{C}$ to a constant weight for dry weight determination. $\mathrm{P}$ content in shoots, roots and nodules were measured by the photometric method at $450 \mathrm{~nm}$ after digesting with a mixture of concentrated $\mathrm{H}_{2} \mathrm{SO}_{4}$ and $\mathrm{H}_{2} \mathrm{O}_{2}$.

Nitrogenase activity Nodule nitrogenase activity was measured by the acetylene reduction assay. Fresh nodules were placed in a closed gas reaction bottle and injected with $10 \mathrm{~mL}$ acetylene gas for $2 \mathrm{~h}$ at $28^{\circ} \mathrm{C}$. Thereafter, the ethylene was measured by gas chromatography (7820A GC system; Agilent Technologies). A standard curve for ethylene was developed according to the standard peak area of ethylene to calculate the ethylene content. Nitrogenase activity was calculated as milliliter ethylene $\mathrm{h}^{-1} \mathrm{~g}^{-1}$ nodule.

Phytase and APase activities APase and phytase were extracted from leaves, roots, and nodules by enzymic reagents according to the manufacturers' recommendations (www.geruisi-bio.com, China). APase activity was defined as the amount of p-nitrophenol (PNP) produced by hydrolyzing $1 \mu$ mol of p-nitrophenyl phosphate (PNPP) per minute per gram of fresh sample at $37^{\circ} \mathrm{C}$. Phytase activity was calculated as $1 \mu \mathrm{mol}$ of $\mathrm{Pi}$ released per minute per gram of fresh sample at $37^{\circ} \mathrm{C}$ and $\mathrm{pH} 5.5$.

RT-PCR of phytase gene in nodules Total RNA was extracted from nodules, using Trizol reagent according to the manual (SinoGene, China). First- strand cDNA was synthesized from 2 mg DNaseI treated RNA (Fermentas). The qRT-PCR analysis was conducted using $2 \times \mathrm{SG}$ Green monitored qRT-PCR (SinoGene, China) and a StepOnePLUS qRT-PCR system (USA). The gene expression analysis had three biological replications. Relative expression level was calculated from the ratio of expression levels of candidate genes to expression level of the housekeeping gene, TEFS1.

\section{Statistical analyses}

Data in this study were reported as means \pm standard deviation $(\mathrm{SD})$ of the four replicates. Data were subjected to a one-way ANOVA, and significant differences between $\mathrm{P}$ levels and cropping patterns were measured by $(\mathrm{LSD})$ test $(\mathrm{P} \leq 0.05)$. All statistical analyses in this study were conducted with SPSS 20.0 (USA).

\section{References}

[1] Shen, J.B., Yuan, L.X. \& Zhang, J.L. Phosphorus dynamics: From soil to plant. Plant Physiol 156: 997-1005(2011).

[2] Cordell, D. \& White, S. Life's bottleneck: Sustaining the world's phosphorus for a food secure future. Annu Rev Env Resour 39: 161-88(2014).

[3] Vance, C.P., Uhde, S.C. \& Allan, D.L. Phosphorus acquisition and use: critical adaptations by plants for securing a nonrenewable resource. New Phytol. 157: 423-447(2003).

[4] Achat, D.L. et al. Soil properties controlling inorganic phosphorus availability: general results from a national forest network and a global compilation of the literature. Biogeochemistry 127: 255-272(2016).

[5] Gilbert, N. The disappearing nutrients. Nature 461: 716-718(2009).

[6] Herrera-Estrella, L. \& López-Arredondo, D. Phosphorus: The underrated element for feeding the world. Trends 
Plant Sci. 21: 461-463(2016).

[7] Udvardi, M. \& Poole, P.S. Transport and metabolism in legume-rhizobia symbioses. Annu Rev Plant Biol 64: 781-805(2013).

[8] Valentine, A.J., Kleinert, A. \& Benedito, V.A. Adaptive strategies for nitrogen metabolism in phosphate deficient legume nodules. Plant Sci 256: 46-52(2017).

[9] Cabeza, R.A. et al. RNA-seq transcriptome profiling reveals that Medicago truncatula nodules acclimate $\mathrm{N}_{2}$ fixation before emerging P deficiency reaches the nodules. J. Exp. Bot. 65: 6035-6048(2014).

[10] Roux, M.R.L., Kahn, S. \& Valentine, A.J. Organic acid accumulation inhibits N2-fixation in P-stressed lupin nodules. New Phytol. 177: 956-964(2008).

[11] Rotaru, V. \& Sinclair, T.R. Interactive influence of phosphorus and iron on nitrogen fixation by soybean. Environ Exp Bot 66: 94-99(2009).

[12] Hernandez, G. et al. Global changes in the transcript and metabolic profiles during symbiotic nitrogen fixation in phosphorus-stressed common bean plants. Plant Physiol 151: 1221-1238(2009).

[13] Qin, L. et al. The high-affinity phosphate transporter GmPT5 regulates phosphate transport to nodules and nodulation in soybean. Plant Physiol 159: 1634-1643(2012).

[14] Thuynsma, R., Valentine, A. \& Kleinert, A. Phosphorus deficiency affects the allocation of below-ground resources to combined cluster roots and nodules in Lupinus albus. J Plant Physiol 173: 1-7(2014).

[15] Lu, M.Y. et al. Spatial divergence of PHR-PHT1 modules maintains phosphorus homeostasis in soybean nodules. Plant Physiol 10: 1-19(2020).

[16] Sulieman, S. \& Tran, L.S.P. Phosphorus homeostasis in legume nodules as an adaptive strategy to phosphorus deficiency. Plant Sci 221: 1-8(2015).

[17] Bedoussac, L. et al. Ecological principles underlying the increase of productivity achieved by cereal-grain legume intercrops in organic farming. A review. Agron Sustain Dev 35: 911-935(2015).

[18] Zhang, D. et al. Increased soil phosphorus availability induced by faba bean root exudation stimulates root growth and phosphorus uptake in neighbouring maize. New Phytol 209: 823-831(2016).

[19] Kermah, M. et al. Maize-grain legume intercropping for enhanced resource use efficiency and crop productivity in the Guinea savanna of northern Ghana. Field Crop Res 213: 38-50(2017).

[20] Tian, J.H. et al. Soybean (Glycine $\max ($ L.) Merrill) intercropping with reduced nitrogen input influences rhizosphere phosphorus dynamics and phosphorus acquisition of sugarcane (Saccharum officinarum). Biol Fert Soils 56: 1-9(2020).

[21] Xu, Z. et al. Intercropping maize and soybean increases efficiency of land and fertilizer nitrogen use; A meta-analysis. Field Crop Res 246: 1-10(2020).

[22] Li, L. et al. Root exudates drive interspecific facilitation by enhancing nodulation and N2 fixation. PANS 113: 6496-6501(2016).

[23] Hu, F.L. et al. Improving $\mathrm{N}$ management through intercropping alleviates the inhibitory effect of mineral $\mathrm{N}$ on nodulation in pea. Plant Soil 412: 235-251(2017).

[24] Liu, Y.C. et al. Interactive influences of intercropping by nitrogen on flavonoid exudation and nodulation in faba bean. Scientific Reports 9: 1-11(2019).

[25] Duff , S.M.G., Sarath, G \& Plaxton, W.C. The role of acid phosphatases in plant phosphorus metabolism. Plant Physiol 90: 791-800(1994).

[26] Doolette, A.L. \& Smernik, R.J. Phosphorus speciation of dormant grapevine (Vitis vinifera L.) canes in the Barossa Valley, South Australia. Aust J Grape Wine Res 22: 462-468(2016).

[27] Liu, S. et al. Characterization of plant-derived carbon and phosphorus in lakes by sequential fractionation and NMR spectroscopy. Sci Total Environ 566:1398-1409(2016). 
[28] Tang, H.L. et al. Spatial distribution and expression of intracellular and extracellular acid phosphatases of cluster roots at different developmental stages in white lupin. J Plant Physiol 170: 1243-1250(2013).

[29] Inal, A. et al. Peanut/maize intercropping induced changes in rhizosphere and nutrient concentrations in shoots. Plant Physiol. Biochem. 45: 350-356(2007).

[30] Bargaz, A. et al. Species interactions enhance root allocation, microbial diversity and $\mathrm{P}$ acquisition in intercropped wheat and soybean under P deficiency. Appl Soil Ecol 120: 179-188(2017).

[31] Araújo, A.P., Plassard, C. \& Drevon, J.J. Phosphatase and phytase activities in nodules of common bean genotypes at different levels of phosphorus supply. Plant Soil 312: 129-138(2008).

[32] Bargaz, A. et al. Differential expression of trehalose 6-P phosphatase and ascorbate peroxidase transcripts in nodule cortex of Phaseolus vulgaris and regulation of nodule $\mathrm{O}_{2}$ permeability. Planta 238:107-119(2013).

[33] Lazali, M. et al. A phytase gene is overexpressed in root nodules cortex of Phaseolus vulgaris-rhizobia symbiosis under phosphorus deficiency. Planta 238:317-324(2013).

[34] Oldroyd, G.E. \& Dixon, R. Biotechnological solutions to the nitrogen problem. Curr Opin Biotech 26: 19-24 (2014).

[35] Wang, G. et al. Allocation of nitrogen and carbon is regulated by nodulation and mycorrhizal networks in soybean/maize intercropping system. Frontiers Plant Sci 7: 1-11(2016).

[36] Zhao, T. et al. Improved post-silking light interception increases yield and P-use efficiency of maize in maize/soybean relay strip intercropping. Field Crop Res 262: 108054(2021).

[37] Zhang, R. et al. Yield and nutrient uptake dissected through complementarity and selection effects in the maize/soybean intercropping. Food Energy Secur 10: 1-15(2021).

[38] Chen, Z.J. et al. Identification of differentially expressed proteins in soybean nodules under phosphorus deficiency through proteomic analysis. Proteomics 11: 4648-4659(2011).

[39] Brooker, R.W. et al. Improving intercropping: a synthesis of research in agronomy, plant physiology and ecology. New Phytol. 206: 107-117(2015).

[40] Jensen, E.S., Peoples, M.B. \& Hauggaard-Nielsen, H. Faba bean in cropping systems. Field Crop Res 115: 203-216(2010).

[41] Rose, T.J. et al. Integration and potential nitrogen contributions of green manure inter-row legumes in coppiced tree cropping systems. Eur J Agron 103: 47-53(2009).

[42] Schulze, J. et al. Nitrogen fixation by white lupin under phosphorus deficiency. Ann Bot 98: 731-740(2006).

[43] Sulieman, S. et al. Growth and nodulation of symbiotic Medicago truncatula at different levels of phosphorus availability. J Exp Bot 64: 2701-2712(2013).

[44] Jebara, M. et al. Nodule conductance varied among common bean (Phaseolus vulgaris) genotypes under phosphorus deficiency. J Plant Physiol 162: 309-315(2005).

[45] Esfahani, M.N. et al. Adaptation of the symbiotic Mesorhizobium-chickpea relationship to phosphate deficiency relies on reprogramming of whole-plant metabolism. PNAS 22: 4610-4619(2016).

[46] Mandri, B. et al. Interactions between common bean genotypes and rhizobia strains isolated from Moroccan soils for growth, phosphatase and phytase activities under phosphorus deficiency conditions. J Plant Nutr 35 : 1477-1490(2012).

[47] Vardien, W., Steenkamp, E.T. \& Valentine, A.J. Legume nodules from nutrient-poor soils exhibit high plasticity of cellular phosphorus recycling and conservation during variable phosphorus supply. $J$ Plant Physiol 191: 73-81(2016).

[48] Bargaz, A. et al. Physiological and molecular aspects of tolerance to environmental constraints in grain and forage legumes. Int. J. Mol. Sci. 16: 18976-19008(2015).

[49] Lazali, M. \& Drevon, J.J. Role of acid phosphatase in the tolerance of the rhizobial symbiosis with legumes to 
phosphorus deficiency. Symbiosis 76: 221-228(2018).

[50] Kouas, S. et al. Effect of phosphorus deficiency on acid phosphatase and phytase activities in common bean (Phaseolus vulgaris L.) under symbiotic nitrogen fixation symbiosis. Symbiosis 47: 141-149(2009).

[51] Makoudi, B. et al. Phosphorus deficiency increases nodule phytase activity of faba bean-rhizobia symbiosis. Acta Physiol Plant 40: 63-72(2018).

\section{Acknowledgments}

This work was financially supported by the National Key R\&D Program (Grant Number 2017YFD0200200/207), and the National Natural Science Foundation Project (Grant Number $31760615,31760611)$.

\section{Author Contributions}

Qin, X.M. conducted the experiments and analyzed data. The manuscript was written through contributions of Qin, X.M., Pan, H.N., Xiao, J.X., Tang, L. and Zheng, Y. conceived and supervised the study. All authors have given approval to the final version of the manuscript.

\section{Additional Information}

Competing Interests: The authors declare no competing interests. 
Figures
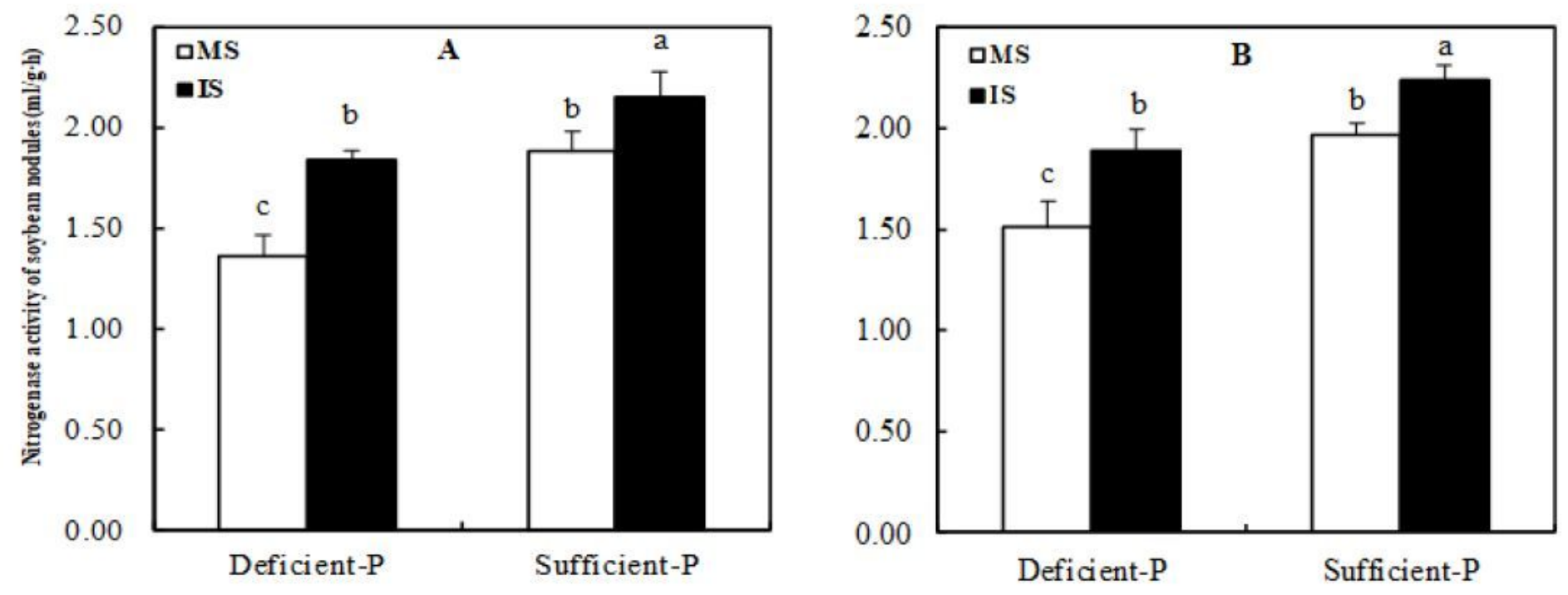

Figure 1

"Please see the Manuscript PDF file for the complete figure caption". 

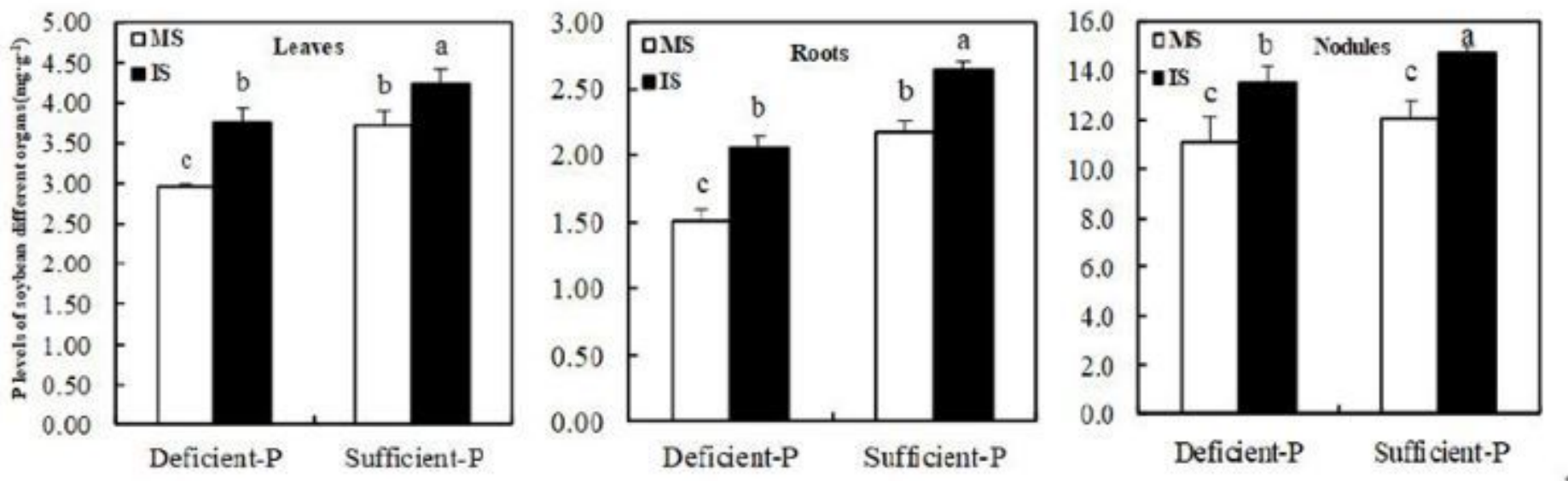

Soil experiment
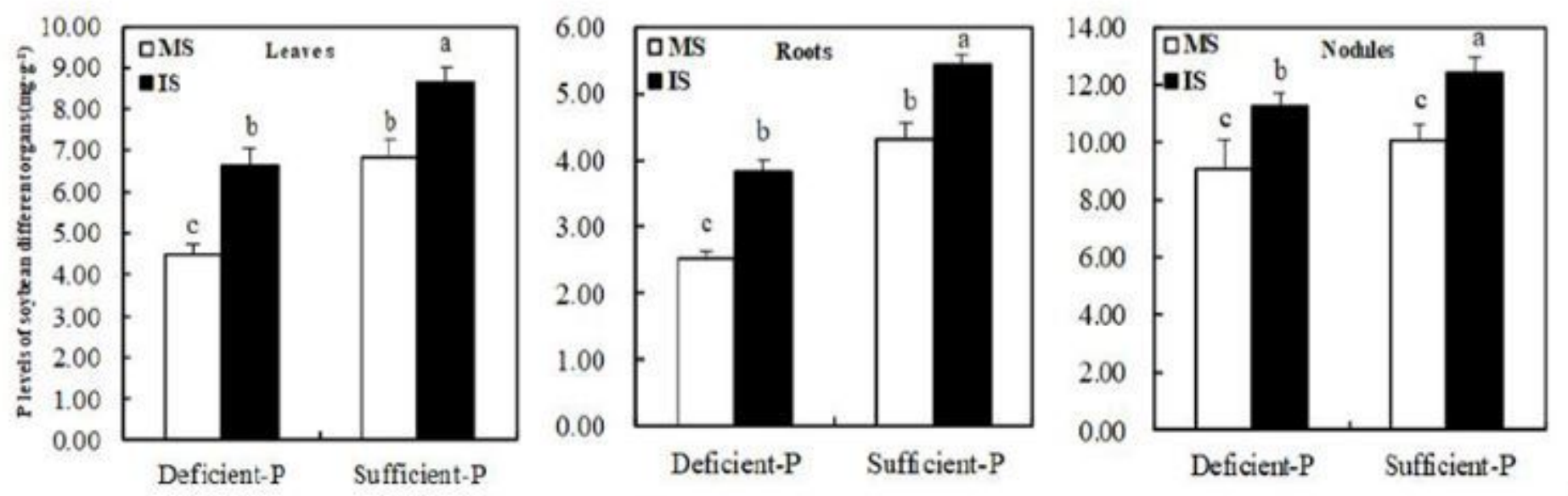

Hydroponic experiment

Figure 2

"Please see the Manuscript PDF file for the complete figure caption". 

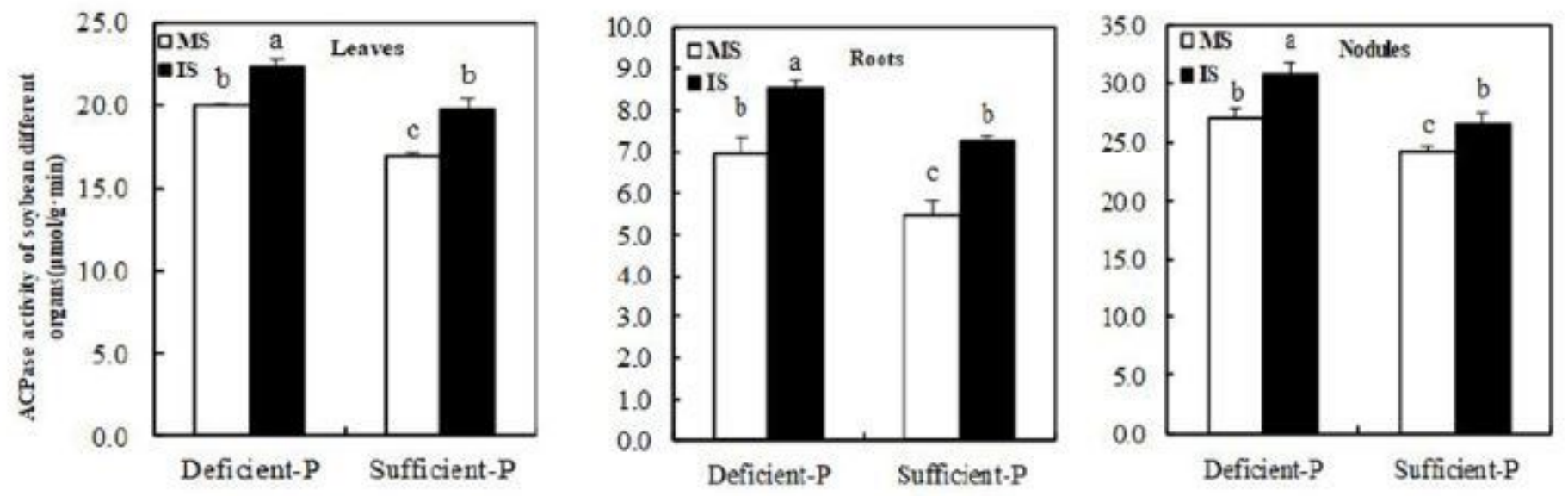

\section{Soil experiment}
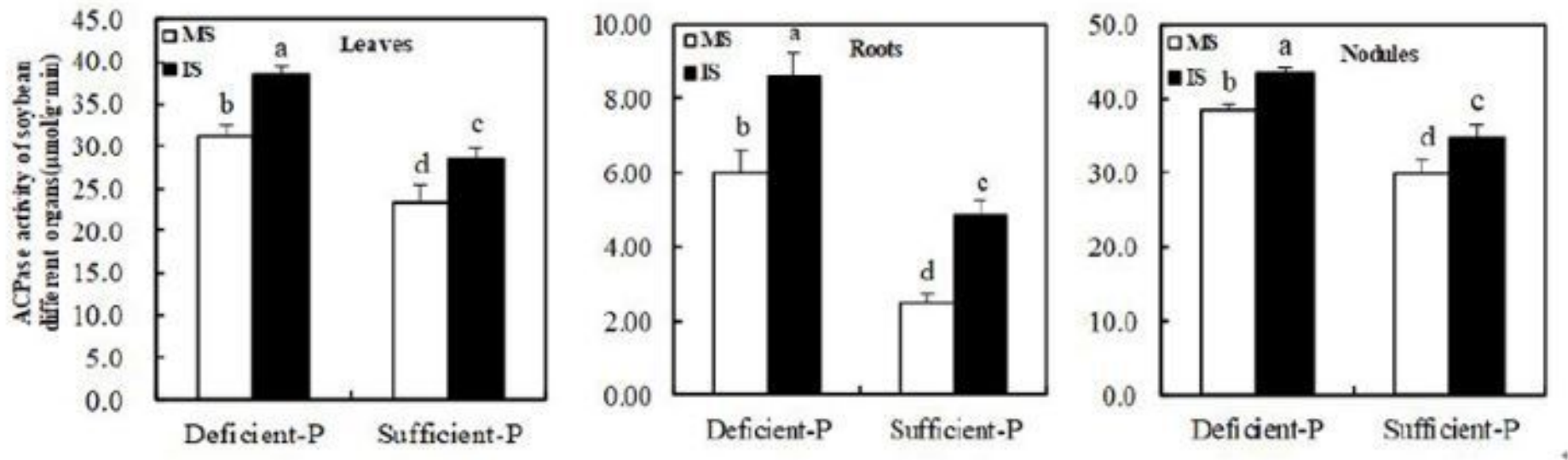

Hydroponic experiment

Figure 3

"Please see the Manuscript PDF file for the complete figure caption". 

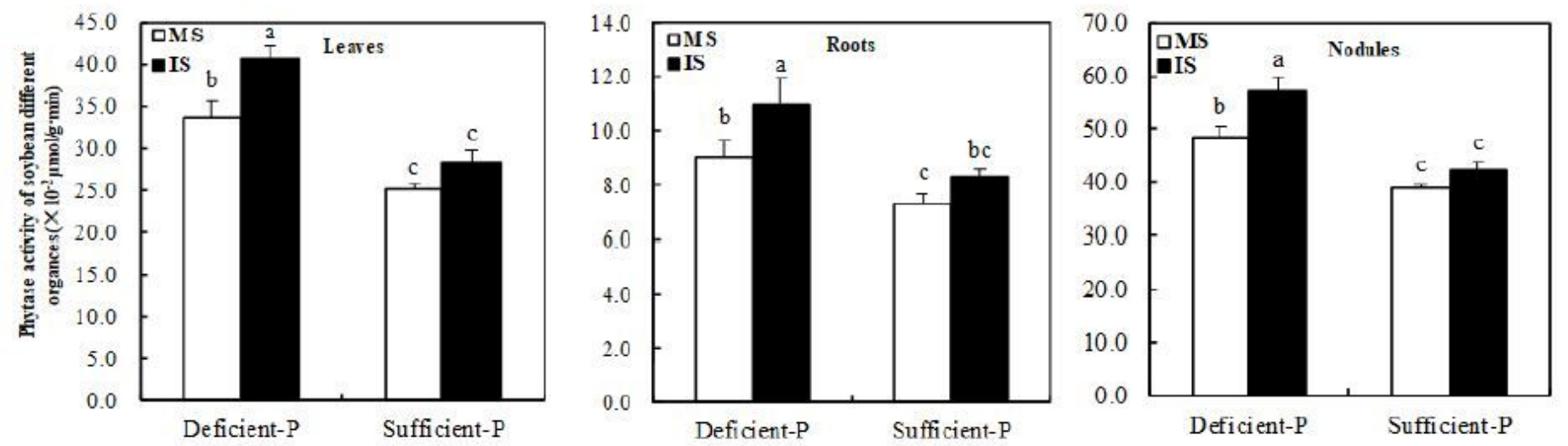

Soil experiment
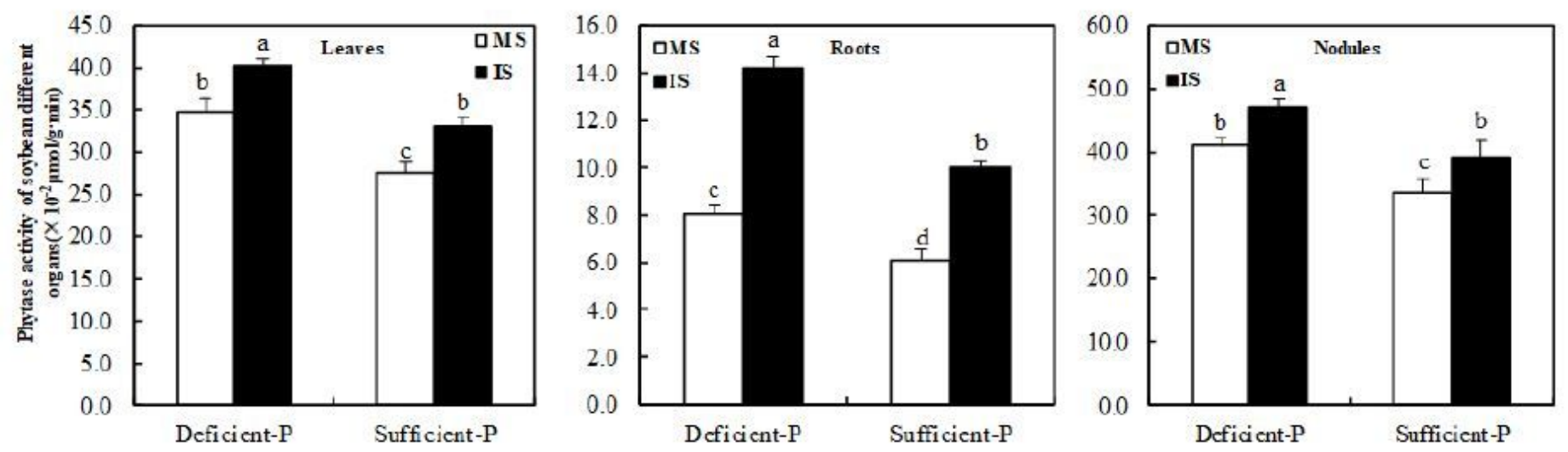

Hydroponic experiment

Figure 4

"Please see the Manuscript PDF file for the complete figure caption".
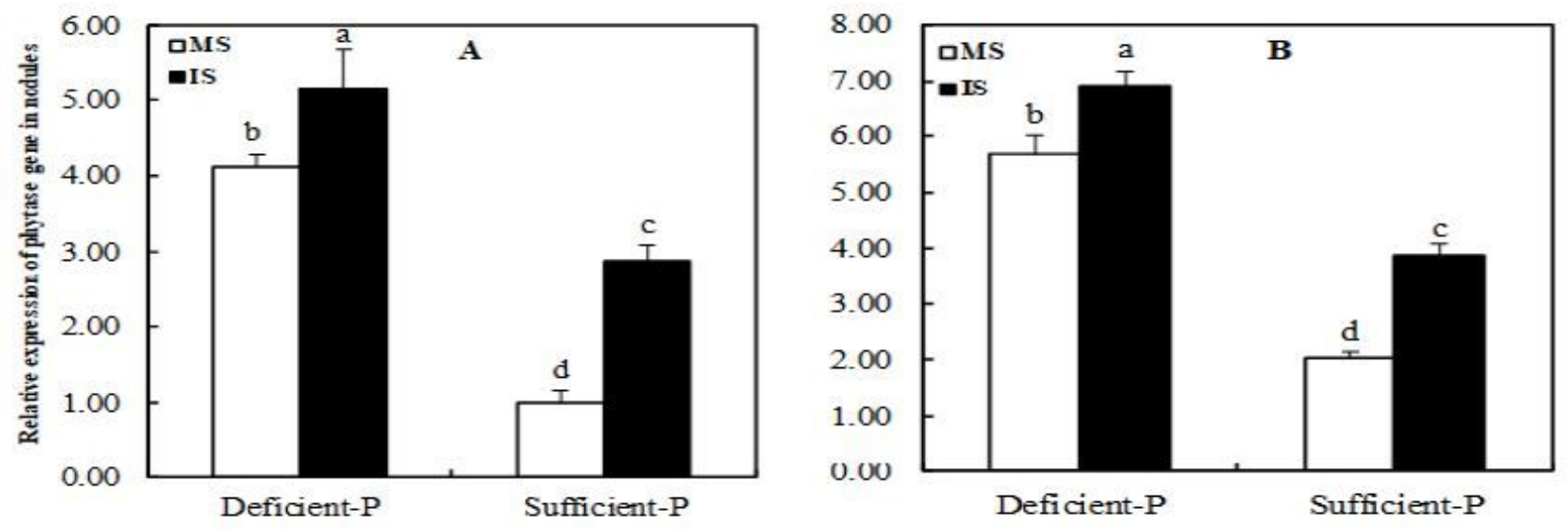

Figure 5

"Please see the Manuscript PDF file for the complete figure caption". 